\title{
DEVELOPMENT OF CLASS MANAGEMENT IN INCREASING LEARNING EFFICIENCY IN ISLAMIC EDUCATION
}

\author{
Mohammad Riza Zainuddin \\ STAI Muhammadiyah Tulungagung \\ riza77.zainuddin@gmail.com
}

\begin{abstract}
The decentralized system of education in this era give a chance to each school institutions to improve the quality of schools that participate in improving the quality of education responded by seeking to every teacher to be creative to improve classroom management appropriately for learning run efficiently and effectively. Arguing that the media class is meeting all the educational component as well as the cutting edge and also educational base. This class management concept seeks to provide a solution to the problem in the class, whose scope is not limited to delivery of content, but also includes some things thoroughly to organize classes include: first academic activities such as planning, implementation and assessment of learning. Both administrative activities that include activities such as procedural and organizational arrangement of the room, grouping students in the division of tasks, classroom discipline, the procurement of test, organizing classes, reporting. So the concept of classroom management is trying to empower the potential of existing classes as optimally as possible to support the process of educational interaction in achieving learning goals that are particularly effective in the material Islamic Education.
\end{abstract}

Keywords: Class management, Efficiency, Islamic Education Learning

\section{Introduction}

The learning process occurs because of the interaction between a person and his environment. Therefore learning can occur anytime and anywhere. As for simple learning can be interpreted as a process that occurs because of an effort to make changes to the human self who do, with the intention of obtaining changes in him at the level of knowledge, skills and attitudes and there is always an effort in the form of training (Arikunto, 1990: 19).

The teaching and learning process that is held in several schools as a center for formal education is more intended to direct change in self-planned manner both in terms of cognitive, affective and psychomotor. In the learning interaction 
is very influenced by several components which include: students, teachers, principals, subject matter, infrastructure (libraries), the environment and several other facilities that fulfill the learning process so that it will support the effectiveness of the learning process.

The role of the teacher is very important in education. The good or bad of education is influenced by how a teacher can manifest and apply his contribution into a formal institution to realize the nation's intelligence and state ideals, so that between teachers and education is a component that cannot be separated. If the word "education" means that there are educators and some are educated, then it means teachers and students. A teacher or educator works according to the school curriculum. Therefore, the frequency of education in educational institutions is expected to be able to produce students who can complete their education according to predetermined targets, with reference to the curriculum that is used as a learning program. If the interaction between the curriculum taught by the teacher and the student's ability to absorb the material becomes a unified whole, the maximum target will be achieved in a balanced manner.

In reality, the quality of Islamic Education in today's field of education is still vulnerable because it has not reached the desired target adequately, especially in public schools. In addition to these realities, there is an assumption that "In school life we often see teachers who can be said to be unsuccessful in teaching. The indicator of teacher failure is student achievement that is low, not in accordance with the standard or specified size limit. This failure is not only the teacher's failure to teach his task, namely mastering the subject matter when delivering it, but the teacher's ignorance in managing the class. This results in the ineffectiveness of learning especially Islamic Education so that the quality of students decreases (Arikunto, 1990: 190-191).

To improve the effectiveness of learning, especially in the field of study of Islamic Education, there are things that need to be considered by a teacher. Teachers should be clever in class management so that learning can run effectively and optimally. The scope of classroom management consists of academic activities in the form of planning, implementing and evaluating 
learning, as well as administrative activities that include procedural and organizational activities such as room arrangement, grouping students in task division, enforcement of class discipline, procurement of tests, class organization, recording class and reporting (www.pikiran-rakyat.com).

With the management of this class, students will be motivated in learning, especially in the management of the classroom atmosphere, which in particular is an important capital for the clarity of the mind in attending lessons, so that children will feel comfortable and enthusiastic. By learning conducive Islamic Education and an atmosphere that tends to be recreational, it will be able to encourage students to develop their creative potential.

Learning is a process that is characterized by changes in a person. While learning is part of the learning process can be addressed in various forms, such as changes in knowledge, understanding attitudes, and behavior, skills, skills, habits and are some other aspects that exist in individuals who learn.

Behavior as a process of learning outcomes is influenced by several factors both internal and external. The internal factors are the abilities possessed by students, namely their interests and concerns, business habits and motivation and several other factors. While external factors in education and teaching can be divided into three environments, namely the family, school and community environment. All of that greatly affects learning, especially in the school environment, which is about the management of classes that will affect the learning process of students in increasing learning effectiveness more optimally (Sudjana, 1989: 54).

As a result the role of the effectiveness of the education of Islam in schools as a provider of spiritual value to the welfare of the community began to be questioned. Assuming that religious education is well done, then people's lives will be much better.

Seeing this phenomenon, it is as if Islamic Education is considered to be less contributing towards that direction without seeing the real problem in Islamic Education. However, after being traced it turned out to be a lack of a teacher in playing the role of classroom management. And it is indeed unfair if you have to 
put responsibility on the emergence of the gap between hope and reality to Islamic Education. Because religious education in schools is not the only determining factor in the formation of students' character and personality. Moreover, in the implementation of Islamic Education there are still some weaknesses that encourage consistent improvement. Another weakness, the material of Islamic Education, including material morality that is more focused on enriching knowledge (cognitive) and minimal in the formation of attitudes (affective) and habituation (psychomotor).

\section{Discussion}

\section{Class Management}

In order to implement classroom management effectively and efficiently, teachers must be creative in improving classroom management. The teacher is a role model and direct role model for students in the class. Therefore, the teacher needs to be prepared with all obligations, both management and preparation of the contents of the subject matter. The teacher must organize his class well, schedule lessons, division of tasks, students, cleanliness, beauty and class order. Seating arrangements of students, the placement of equipment must be done as well as possible.

Thus, it means that the class has certain roles and functions that can obviously support the success of the teaching and learning process. So that in order to provide stimulation to students in learning situations and conditions, the class needs to be managed as well as possible. Good relations between teacher and students, students from one to the other are seen as an indication of the success of classroom management. From this it is right to say that dynamic class management is the determinant of the realization of an effective learning process.

And to create an atmosphere that can foster a passion for learning, improve student learning achievement, and more allow teachers to provide guidance and assistance to students in learning, it requires good and adequate classroom 
management (Semiawan, 1992: 64). Careless management of classes can clearly reveal a broken learning process.

\section{Classroom Management Objectives In Learning}

With good classroom management, it is expected to create a condition of proportional learning groups consisting of a good classroom environment that allows students to do according to their abilities, as well as available opportunities to gradually reduce their dependence on the teacher, so that students are able to realize their own activities. This means that students are expected to be able to carry out self-activity and self-control in stages, but definitely towards a more mature level (Qomar, 2002: 283).

In general, the goal of class management in Sudirman's view is to provide facilities for various student learning activities in the social, emotional and intellectual environment in the classroom. The facilities provided allow students to learn and work, creating a social atmosphere that provides satisfaction, an atmosphere of discipline, intellectual, emotional development and an appreciation of students.

\section{The Key to Success in Successful Classroom Management}

a. Preventive Procedures

Preventive business procedures are the initiative of teachers and homeroom teachers to create new conditions from ordinary interactions to educative interactions, by constantly arousing student motivation. What is done in this procedure according to Maslahah in his book Mujamil Qomar is:

1) Increased awareness of teachers as educators, that whatever the style of the educational process that occurs in students is the responsibility of the teacher fully.

2) Increased awareness of students, in this case students must be aware of their rights and obligations as students. 
3) Appearance of the teacher's attitude. The teacher's attitude towards students must be based on a sincere and warm attitude naturally in supporting educational activities.

4) Introduction to student behavior.

5) Discover alternative classroom management. By knowing students' behavior both those who support and reject it by setting alternative solutions

6) Making a social contract. Social contracts are essentially norms / rules and class rules that have been agreed upon as individuals and groups (Qomar, 2002: 293).

b. Curative Procedure

Curative procedure is the initiative of the teacher and homeroom teacher to overcome the form of action of students who are seen as having a negative influence on the teaching and learning process by stopping their actions while at the same time guiding them to have actions supporting the teaching and learning process. What can be done in Maslahah's view is also:

1) Step identification case: understanding and investigating student behavior deviations that interfere with the education process in the classroom.

2) Step problem analysis: knowing the background and the causes of deviant behavior to find the source.

3) Determination of alternative solutions: the teacher tries to overcome the problem in accordance with the situation at hand by using the right approach.

4) Monitoring steps: conduct monitoring of problem solving efforts that have been carried out.

5) Use feedback.

The two keys to the success of class management pay attention to the competence of teachers and guardians of the classroom as key holders is the main determinant of the success of classroom management 


\section{Understanding Learning}

The process of learning action is basically internal, but the process is influenced by external factors. In learning, educators must really be able to attract the attention of students to be able to devote all their energy so that they can carry out learning activities optimally and obtain learning outcomes as expected.

Learning is a series of external events of students designed to support internal learning processes. These learning events are designed to enable students to process real information in order to achieve their intended goals. To achieve learning goals, educators should really master the ways to design learning so that students are able to learn optimally. Some learning theories describe learning as fallow's:

1. Business educators shape desired behavior by providing an environment, so that the stimulus (environmental) relationship occurs with student behavior.

2. The way educators provide opportunities for students to think to understand what is learned.

3. Give freedom to students to choose learning materials and how to learn them according to their interests and abilities.

The learning process is a process of communication between educators and students, or between students. The process of communication is done verbally (verbally) and can also be nonverbal, such as the use of computers in learning. The essence of learning is characterized by a series of communication activities.

Communication in learning is intended to help the learning process. Communication activities can be carried out independently, namely, such as reviewing books, conducting laboratory activities or completing inquiry projects, and can also be done in groups as well as the learning process in the classroom. The advantage of independent learning is that students are ultimately able to use self-learning management skills and strategies. 


\section{Characteristics of Learning}

There are three distinctive features of the learning system, which are:

1. The plan is structuring energy, material, and procedures, which are elements of the learning system, in a specific plan.

2. Interdependence, between the elements of a learning system that are harmonious in a whole. Each element is essential, and each contributes to the learning system.

3. The goal, the learning system has certain goals to be achieved. The main purpose of the learning system is for students to learn.

\section{Application of Class Management in Learning Efficiency in Islamic Education.}

Islamic Education is a process of guidance and help to help the growth and development of personality of students. Islamic Education strives to foster human personality to its ultimate goal, which is happiness and at the same time useful for the benefit of society. Then the correct learning activities of Islamic Religious Education are fostering the human personality to be able to foster a harmonious relationship with God and oneself, as well as for the interests of society, relationship behavior with family, society and the surrounding environment.

Therefore, in the learning process Islamic Education in the classroom needs to be managed in such a way as to help improve the efficiency of learning Islamic Education for the growth and personality development of students. Classroom management is not just how to organize the classroom with all its facilities and infrastructure, but it involves how to interact and the individuals in it. Class management emphasizes more on how individuals in the class can become a community full of brotherhood and kinship. Such a community will develop the personality of both educators and their students. From here, students in the class not only learn aspects of knowledge but also affective aspects and socialities (Riyanto, 2002: 46). 
Class management is the teacher's skill to create a conducive learning climate and control it if there is a disruption in learning. Some principles that must be considered in class management are (1) warmth and enthusiasm, (2) challenge, (3) Varies, (4) flexible, (5) emphasis on positive things, (6) planting selfdiscipline.

Classroom management skills have the following component (Mulyasa, 2004: 91):

a. Creation and maintenance of an optimal learning climate

1) Demonstrate responsiveness by: looking closely, approaching, giving statements and reacting to disturbances in class

2) Share reactions visually and verbally

3) Focus group attention by preparing students for disturbances in class

4) Give instructions and reprimand clearly and wisely

b. Skills related to optimal control of learning conditions, by the way:

1) Modification Of behaviour:

a) Teach new behaviors with examples and habits

b) Improve good behavior through reinforcement

c) Reducing bad behavior with punishment

2) Management Of groups in way (a) increased cooperation and order, (b) handle conflict and minimize problems that arise.

3) Finding and dealing with behaviors that cause problems:

a) The planned neglect.

b) Interference with gestures.

c) Supervise closely.

d) Recognizing students negative feelings.

e) Encourage students to express their feelings.

\section{Conclusion}

In applying classroom management to improve the efficiency of learning Islamic Education includes: learning planning, organizing learning, communicating, method selection, media use, class discipline, class conflict, 
evaluation of learning, room arrangement. The teacher must organize his class well, schedule lessons, division of tasks, students, cleanliness, beauty and class order. Seating arrangements of students, the placement of equipment must be done as well as possible. For success carried out in classroom management related to learning Islamic Education so that more efficiency needs to be done preparing administrative tasks, giving motivation to students, making modules in accordance with the material, overcoming each student's problems, choosing methods, forming discussion groups, improving student discipline. Good relations between teacher and students, students from one to the other are seen as an indication of the success of classroom management. From here it is right to say that dynamic class management is a determinant of the realization of the effective learning process of Islamic Education. 


\section{REFERENCES}

Arikunto, Suharsimi. 1990. Manajemen Pengajaran Secara Manusiawi. Jakarta: PT. Rineka Cipta.

Marland, Michael. 1985. Seni Mengelola Kelas. Disadur dari Craft of the Classroom. Semarang: Dahara Prize.

Mulyasa. 2004. Manajemen Berbasis Sekolah, Konsep Strategi dan Implementasi. Bandung: PT. Remaja Rosdakarya Offset.

Nana Sudjana, Nana. 1989. CBSA Dalam Proses Belajar Mengajar. Bandung: Sinar Baru.

Nawawi, Hadari. 1989. Organisasi Sekolah dan Pengelolaan Kelas Sebagai Lembaga Pendidikan. Bandung: Remaja Rosdakarya.

Qomar, Mujamil. 2002. Meniti Jalan Pendidikan Islam. Yogyakarta: Pustaka Pelajar Offset.

Rohani, Ahmad. 2004. Pengelolaan Pengajaran. Jakarta: PT. Rineka Cipta.

Semiawan, Cony. 1992. Pendekatan Ketrampilan Proses, Bagaimana Mengaktifkan Siswa Dalam Belajar. Jakarta: Grasindo.

Theo Riyanto, Theo. 2002. Pembelajaran Sebagai Suatu Bimbingan Pribadi. Jakarta: PT. Gramedia Widiasarana Indonesia.

Usman, Moh. User. 1995. Menjadi Guru Profesional. Bandung: PT. Remaja Rosdakarya Offset.

Wijaya, Cece dan Rusyan, Tabrani. 1994. Kemampuan Dasar Guru Dalam Proses Belajar Mengajar. Bandung: Remaja Rosdakarya. 